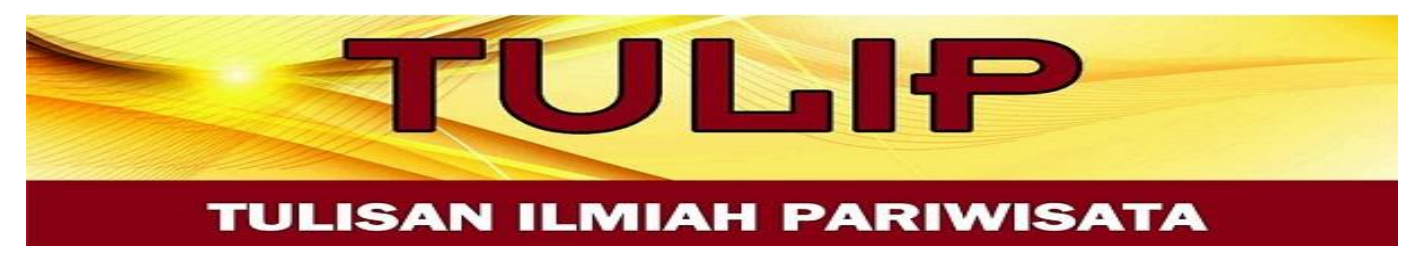

\title{
RESPON MASYARAKAT LOKAL TERHADAP PENGEMBANGAN WISATA HUTAN PINUS SEBAGAI DAYA TARIK WISATA DI DESA DULAMAYO KABUPATEN GORONTALO
}

\author{
Sri Sunarti \\ srisunarti@umgo.ac.id \\ Dosen Pariwisata, FIB_UMGo, Jl.Prof Mansoer Pateda, Indonesia \\ Siti Mulghima Olii \\ sitimughlimailii@gmail.com, \\ Wahawiswa, Pariwisata, FIB_UMGo, Jl.Prof Mansoer Pateda, Indonesia
}

\begin{abstract}
Abstrak
Salah satu Kecamatan yang berada di Kabupaten Gorontalo, yang memiliki pesona alam yang sangat indah dan sangat beragam akan bentuknya yaitu Kecamatan Telaga Jaya, khususnya Desa Pilohayanga yang memanfaatkan Sumber Daya Alam atau Hutan Pinus untuk pembangunan wisata alam. Tempat ini dinamakan Wisata Pinus Ecopark. Wisata Pinus ini memiliki suasana yang asri dan sejuk, dengan pepohonan pinus yang rindang ini memberikan oksigen yang sangat baik untuk pengunjung. Bukan hanya itu, fasilitas yang tersedia di tempat wisata ini juga menjadi nilai tambah yang dapat dinikmati oleh pengujung. Dengan adanya objek-objek foto yang sangat Instagramable, seperti Hiasan payung, Jembatan kayu, Pondokan atau Saung, Ayunan santai dan lain-lain.

Katakunci :Pembangunan, Wisata Hutan Pinus, Dulamayo
\end{abstract}

\section{PENDAHULUAN}

Indonesia merupakan Negara Kepulauan yang indah dan kaya akan hasil alam dan kebudayaan, yang terdiri dari berbagai suku, budaya, ras, agama, maupun sejarah. Setiap pulau maupun daerah tentu mempunyai potensi dan keunikan masing-masing yang menarik dan dapat dikembangkan. Hal ini dapat menjadi modal pertama Indonesia untuk menjadi maju dan terlepas dari kemiskinan. Kekayaan alam dan keberagaman bangsa indonesia dapat menjadi daya tarik wisatawan baik lokal maupun asing. Dengan demikian Indonesia dapat mengembangkan kekayaan akan potensi tersebut menjadi pariwisata.

Available Online at http://journal.umgo.ac.id/index.php/Tulip

TULIP: Tulisan IImiah Pariwisata, Vol. 2, No. 2 Desember 2019, 149-163 


\section{TULISAN ILMIAH PARIMISATA}

Sektor pariwisata ditetapkan sebagai sektor yang penting untuk dikembangkan secara sinergi sebagai sektor unggulan. Melalui pendekatan pariwisata berkelanjutan (sustainable tourism) perlu sinergi antara upaya pelestarian alam dan budaya beserta warisannya untuk menunjang percepatan pembangunan nasional. Pemanfaatan alam dan budaya di sektor pariwisata terus berkembang, namun besarnya potensi sumberdaya alam dan budaya yang tersebar di hampir 17 ribu pulau di Indonesia belum dimanfaatkan sesuai dengan potensi yang dimiliki masing-masing destinasi.

Musanef mengartikan pariwisata sebagai suatu perjalanan yang dilaksanakan untuk sementara waktu, yang dilakukan dari satu tempat ke tempat yang lain untuk menikmati perjalanan bertamasya dan berekreasi. Sedangkan menurut Bambang Supriadi dan Nanny Roenjinandari Pariwisata adalah perjalanan sementara seseorang dari satu tempat ketempat lain untuk mencari kesenangan dan bukan untuk mencari keuntungan. Istilah pariwisata berhubungan erat dengan pengertian perjalanan wisata, yaitu sebagai suatu perubahan tempat tinggal sementara seseorang diluar tempat tinggalnya karena suatu alasan dan bukan untuk melakukan kegiatan yang menghasilkan upah.

Berdasarkan beberapa pendapat diatas dapat diartikan bahwa pariwisata merupakan suatu usaha mencari keseimbangan dan kebahagiaan dengan lingkungan hidup dalam dimensi sosial melalui perjalanan dari satu tempat ke tempat lain yang bersifat sementara yang dilakukan oleh perorangan atau kelompok. Namun pariwisata tidak hanya diartikan sebagai perjalanan saja, pada hakikatnya pariwisata juga sebagai ekonomi kreatif yang merupakan salah satu wujud pemikiran, imajinasi, pengetahuan, kemauan dan kemampuan yang kreatif, yang dapat mempercepat kemajuan pembangunan ekonomi dan perkembangan dunia usaha, melalui terciptanya lapangan pekerjaan bagi diri sendiri dan orang lain secara ekonomi dengan menciptakan ide-ide kreatif dari semua potensi wisata yang ada.

Perkembangan industri pariwisata di indonesia begitu pesat. Terlihat dari data kunjungan wisatawan mancanegara yang selalu meningkat setiap tahunnya. Available Online at http://journal.umgo.ac.id/index.php/Tulip

TULIP: Tulisan IImiah Pariwisata, Vol. 2, No. 2 Desember 2019, 149-163 


\section{TULISAN ILMIAH PARIVISATA}

Berikut ini data kunjungan wisatawan mancanegara pada tahun 2015 hingga tahun 2018:

Tabel 1.1 Data Kunjungan Wisatawan Mancanegara di Indonesia

\begin{tabular}{|c|c|c|c|c|}
\hline \multirow{2}{*}{ Bulan } & \multicolumn{4}{|c|}{ Data Kunjungan Wisatawan Mancanegara } \\
\hline & 2015 & 2016 & 2017 & 2018 \\
\hline Januari & 785.973 & 851.462 & 1.107 .968 & 1.097 .839 \\
\hline Februari & 843.928 & 938.650 & 1.023 .388 & 1.197 .503 \\
\hline Maret & 841.071 & 968.567 & 1.059 .777 & 1.363 .426 \\
\hline April & 801.193 & 956.381 & 1.171 .386 & 1.302 .321 \\
\hline Mei & 852.388 & 983.810 & 1.148 .588 & 1.242 .705 \\
\hline Juni & 851.475 & 925.250 & 1.144 .001 & 1.322 .674 \\
\hline Juli & 879.815 & 1.098 .032 & 1.370 .591 & 1.540 .549 \\
\hline Agustus & 911.704 & 1.087 .404 & 1.393 .243 & 1.511 .021 \\
\hline September & 919.408 & 1.058 .103 & 1.250 .231 & 1.370 .943 \\
\hline Oktober & 877.621 & 1.040 .651 & 1.161 .565 & 1.291 .605 \\
\hline Nopember & 836.133 & 1.002 .333 & 1.062 .030 & 1.157 .483 \\
\hline Desember & 986.339 & 1.113 .328 & 1.147 .031 & 1.405 .554 \\
\hline Total & 10.389 .063 & 12.025 .987 & 14.041 .816 & 15.805 .641 \\
\hline
\end{tabular}

Sumber: www.kemenpar.go.id

Data diatas menunjukan peningkatan jumlah kunjungan wisatawan mancanegara dari tahun ke tahun. Terlihat pada tahun 2015 jumlah kunjungan wisatawan mancanegara adalah sebanyak 10.389.063 jiwa, pada tahun 2016 jumlah kunjungan wisatawan mancanegara meningkat menjadi 12.025.987 jiwa, dan pada tahun 2017 jumlah kunjungan wisatawan mancanegara meningkat lagi menjadi 14.041.816 jiwa, selanjutnya pada tahun 2018 jumlah kunjungan wisatawan mancanegara sebanyak 15.805.641 jiwa.

Melihat jumlah kunjungan wisatawan mancanegara yang terus meningkat Available Online at http://journal.umgo.ac.id/index.php/Tulip

TULIP: Tulisan IImiah Pariwisata, Vol. 2, No. 2 Desember 2019, 149-163 


\section{TULISAN ILMIAH PARIMISATA}

pemerintah mengeluarkan beberapa kebijakan, diantaranya mengenai target jumlah kunjungan wisatawan mancanegara sebanyak 20 juta jiwa di tahun 2019, pengembangan atraksi wisata, memperkuat promosi pariwisata nasional, mendorong investasi dan pembiayaan dalam pengembangan destinasi wisata, dan lain sebagainya.

Salah satu Provinsi di Indonesia yang memiliki potensi akan pariwisata yaitu Provinsi Lampung, khususnya Kabupaten Lampung Barat yang memiliki potensi dan kekayaan alam yang begitu eksotik menjadi tujuan wisatawan, dengan berbagai destinasi pariwisata yang terus berkembang hingga saat ini. Hal ini dapat dilihat dari data kunjungan wisatawan baik nusantara maupun mancanegara. Berikut data perkembangan jumlah kunjungan wisatawan Kabupaten Lampung Barat tahun 2015 hingga tahun 2018:

Tabel 1.2 Data Kunjungan Wisatawan Nusantara dan Mancanegara di Kabupaten Gorontalo

\begin{tabular}{|l|c|c|c|c|}
\hline \multirow{2}{*}{ Wisatawan } & \multicolumn{4}{|c|}{ Tahun } \\
\cline { 2 - 5 } & $\mathbf{2 0 1 5}$ & $\mathbf{2 0 1 6}$ & $\mathbf{2 0 1 7}$ & $\mathbf{2 0 1 8}$ \\
\hline Nusantara & 13.825 & 14.567 & 15.918 & 16.372 \\
\hline Mancanegara & 421 & 396 & 531 & 655 \\
\hline \multicolumn{1}{c|}{ Total } & $\mathbf{1 4 . 2 4 6}$ & $\mathbf{1 4 . 9 6 3}$ & $\mathbf{1 6 . 4 4 9}$ & $\mathbf{1 7 . 0 2 7}$ \\
\hline
\end{tabular}

Sumber: Dinas Kepemudaan Olahraga dan Pariwisata Kabupaten Gorontalo 2019.

Data diatas menunjukan peningkatan jumlah kunjungan wisatawan nusantara maupun mancanegara dari tahun ke tahun. Terlihat pada tahun 2015 jumlah kunjungan wisatawan adalah sebanyak 14.246 jiwa, pada tahun 2016 jumlah kunjungan wisatawan meningkat menjadi 14.963 jiwa, dan pada tahun 2017 jumlah kunjungan wisatawan meningkat lagi menjadi 16.449 jiwa, Available Online at http://journal.umgo.ac.id/index.php/Tulip

TULIP: Tulisan IImiah Pariwisata, Vol. 2, No. 2 Desember 2019, 149-163 


\section{TULISAN ILMIAH PARIMISATA}

selanjutnya pada tahun 2018 jumlah kunjungan wisatawan sebanyak 17.027 jiwa.

Salah satu Kecamatan yang berada di Kabupaten Gorontalo, yang memiliki pesona alam yang sangat indah dan sangat beragam akan bentuknya yaitu Kecamatan Telaga Jaya, khususnya Desa Pilohayanga yang memanfaatkan Sumber Daya Alam atau Hutan Pinus untuk pembangunan wisata alam. Tempat ini dinamakan Wisata Pinus Ecopark.

Wisata Pinus ini memiliki suasana yang asri dan sejuk, dengan pepohonan pinus yang rindang ini memberikan oksigen yang sangat baik untuk pengunjung. Bukan hanya itu, fasilitas yang tersedia di tempat wisata ini juga menjadi nilai tambah yang dapat dinikmati oleh pengujung. Dengan adanya objek-objek foto yang sangat Instagramable, seperti Hiasan payung, Jembatan kayu, Pondokan atau Saung, Ayunan santai dan lain-lain.

Wisata Pinus dibentuk dengan adanya kerjasama antar lembaga terkait seperti, KPHL II Liwa (Kelompok Pecinta Hutan Lindung), KPA Green (Kelompok Pecinta Alam Hijau), HPPHL (Himpunan Pemuda Peduli Hutan dan Lingkungan) serta Kelompok HKM (Hutan Kemasyarakatan) yang membentuk konsorsium yang bernama West Land. Ke-Empat lembaga tersebut secara terus menerus mengelola dan mengembangkan hutan pinus ini untuk dijadikan tempat wisata, dan mulai mempromosikan tempat ini melalui media sosial, dintaranya melalui Instagram dengan Follower sebanyak 1.643, Facebook, dan Youtube.

Berdasarkan hasil Survey dengan 5 pengelola wisata, jumlah pengunjung wisata Pinus Ecopark setiap bulannya selalu meningkat. Berikut data Pengunjung wisata Pinus Ecopark pada tahun 2018 dan 2019:

Tabel 1.3 Jumlah Pengunjung Wisata Pinus Dulamayo

\begin{tabular}{|l|c|c|}
\hline \multirow{2}{*}{ Bulan } & \multicolumn{2}{|c|}{ Tahun } \\
& $\mathbf{2 0 1 8}$ & \\
\cline { 2 - 3 } & & 1.272 \\
\hline Januari & 408 & 19 \\
\hline
\end{tabular}

Available Online at http://journal.umgo.ac.id/index.php/Tulip

TULIP: Tulisan IImiah Pariwisata, Vol. 2, No. 2 Desember 2019, 149-163 


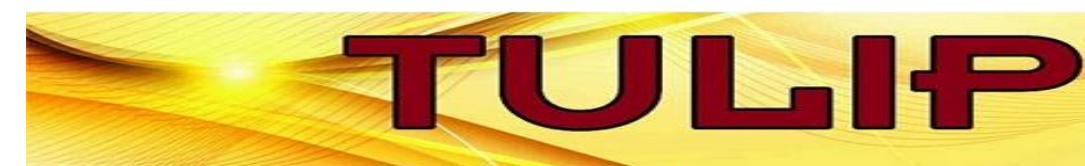

TULISAN ILMIAH PARINISATA

\begin{tabular}{|l|c|l|}
\hline Februari & 600 & 1.056 \\
\hline Maret & 648 & 1.128 \\
\hline April & 744 & 1.200 \\
\hline Mei & 696 & 1.320 \\
\hline Juni & 792 & 1.512 \\
\hline Juli & 1.248 & 1.560 \\
\hline Agustus & 1.200 & 1.680 \\
\hline September & 960 & 1.728 \\
\hline Oktober & 1.080 & 1.763 \\
\hline Nopember & 1.176 & \\
\hline Desember & 1.200 & \\
\hline
\end{tabular}

Sumber: Hasil Wawancara dengan Pengelola Wisata Pinus, 2019.

Data diatas menunjukan bahwa pengunjung wisata pinus Dulamayo ratarata mengalami peningkatan setiap bulannya. Terlihat jumlah pengunjung pada bulan Januari hingga bulan Maret tahun 2018 terus mengalami peningkatan. Namun pada bulan Mei mengalami penurunan. Dan mengalami peningkat lagi pada bulan Juni dan Juli. Tetapi pada bulan Agustus mengalami penurunan hingga September, kemudian terus meningkat pada bulan Oktober hingga Januari 2019. Tetapi pada bulan Februari 2019 mengalami penurunan. Dan pada bulan Maret mengalami peningkatan terus menerus hingga November 2019.

Berdasarkan hasil Survey dengan 7 pengunjung wisata, dua diantaranya mengutarakan bahwa promosi yang dilakukan masih mengandung unsur penipuan yang membuat pengunjung kecewa, karena gambar yang di unggah di Instagram tidak sesuai dengan realita, bahkan beberapa spot foto yang telah di unggah sudah tidak ada lagi di lokasi. Selain itu keberadaannya masih belum banyak diketahui oleh khalayak luas, karena kurang aktifnya admin dalam melakukan promosi, baik dalam me-Repost foto, maupun mengolah kata dalam Available Online at http://journal.umgo.ac.id/index.php/Tulip

TULIP: Tulisan IImiah Pariwisata, Vol. 2, No. 2 Desember 2019, 149-163 


\section{TULISAN ILMIAH PARIMISATA}

berpromosi. Padahal bila dikelola dengan baik tentu wisata tersebut memiliki potensi yang besar, mampu mengangkat ekonomi masyarakat sekitar, perbaikan lingkungan hidup, dan peningkatan ilmu pengetahuan teknologi.

Berdasarkan uraian diatas maka peneliti tertarik mengadakan penelitian dengan judul "Respon Masyarakat Lokal Terhadap Pengembangan Hutan Pinus Sebagai Daya Tarik Wisata Di Desa Dulamayo Kabupaten Gorontalo

\section{HASIL DAN PEMBAHASAN}

\section{A. Konsep Pariwisata}

Istilah pariwisata berasal dari dua suku kata, yaitu pari dan wisata. Pari yang berarti banyak, berkali-kali atau berputar-putar. Wisata berarti perjalanan atau berpergian. Jadi pariwisata dapat diartikan perjalanan yang dilakukan berkali-kali atau berputar-putar dari suatu tempat ke tempat yang lain. Namun kepariwisataan tidak hanya diartikan sebagai perjalanan saja, akan tetapi memilki arti yang sangat luas, yakni berkaitan dengan obyek dan daya tarik wisata yang dikunjungi, sarana transportasi yang digunakan, pelayanan, akomodasi, rumah makan, hiburan, interaksi sosial antara wisatawan dan penduduk lokal setempat. Menurut Undang-undang RI nomor 10 tahun 2009 tentang Kepariwisataan, pengertian wisata adalah kegiatan perjalanan yang dilakukan oleh seseorang atau sekelompok orang dengan mengunjungi tempat tertentu untuk tujuan rekreasi, pengembangan pribadi, atau mempelajari keunikan daya tarik wisata yang dikunjungi, dalam jangka waktu sementara.

Pariwisata adalah perjalanan sementara seseorang dari satu tempat ketempat lain untuk mencari kesenangan dan bukan untuk mencari keuntungan. Musanef mengartikan pariwisata sebagai suatu perjalanan yang dilaksanakan untuk sementara waktu, yang dilakukan dari satu tempat ke tempat yang lain untuk menikmati perjalanan bertamasya dan berekreasi.

Sedangkan definisi Pariwisata menurut (Kementerian Hukum dan Hak Available Online at http://journal.umgo.ac.id/index.php/Tulip

TULIP: Tulisan IImiah Pariwisata, Vol. 2, No. 2 Desember 2019, 149-163 


\section{TULISAN ILMIAH PARIMISATA}

Asasi Manusia, 2009) adalah berbagai macam kegiatan wisata dan didukung berbagai fasilitas serta pelayanan yang disediakan oleh

masyarakat, pengusaha, pemerintah, dan pemerintah daerah (Bab 1, Pasal 1, Ayat 3).38

Menurut definisi yang lebih luas pariwisata adalah perjalanan dari satu tempat ke tempat lain, bersifat sementara, dilakukan perorangan atau kelompok, sebagai usaha mencari keseimbangan dan kebahagiaan dengan lingkungan hidup dalam dimensi sosial, budaya, alam, dan ilmu. Sedangkan menurut arti terminologi, pariwisata dapat terbentuk apabila ada pelaku wisata yang memang mempunyai motivasi untuk melakukan perjalanan wisata, ketersediaan infrastruktur pendukung, keberadaan objek wisata dan atraksi wisata yang didukung dengan sistem promosi dan pemasaran yang baik serta pelayanan terhadap para pelaku wisata.39

Berdasarkan beberapa pendapat diatas pariwisata merupakan suatu usaha mencari keseimbangan dan kebahagiaan dengan lingkungan hidup dalam dimensi sosial melalui perjalanan dari satu tempat ke tempat lain yang bersifat sementara yang dilakukan oleh perorangan atau kelompok. Namun pariwisata tidak hanya diartikan sebagai perjalanan saja, pada hakikatnya pariwisata juga merupakan salah satu faktor yang penting bagi pertumbuhan ekonomi, karena dengan adanya pariwisata dapat membantu masyarakat sekitar dalam menciptakan lapangan pekerjaan di area wisata.

\section{B. Prinsip Pengembangan Wisata}

Sebuah destinasi dapat dikatakan akan melakukan pengembangan wisata jika sebelumnya sudah ada aktivitas wisata. Untuk dapat meningkatkan potensi pariwisatanya, yang perlu dilakukan adalah merencanakan pengembangan wisata agar dapat lebih baik dari sebelumnya. Tiga prinsip utama dalam sustainability development:

Available Online at http://journal.umgo.ac.id/index.php/Tulip

TULIP: Tulisan IImiah Pariwisata, Vol. 2, No. 2 Desember 2019, 149-163 


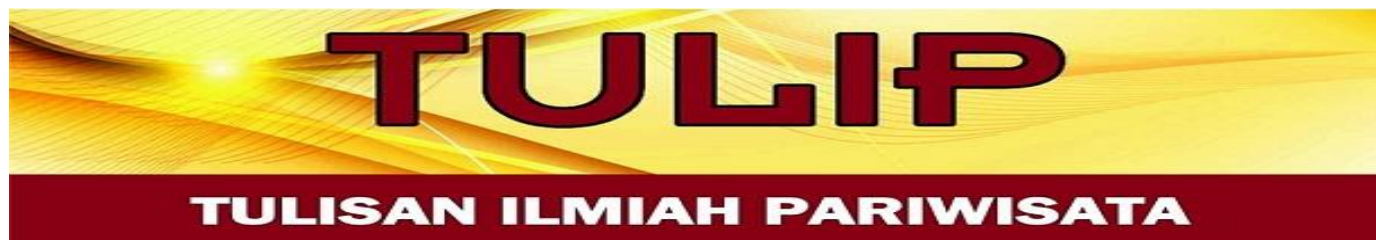

a) Ecological Sustainability, yakni memastikan bahwa pengembangan yang dilakukan sesuai dengan proses ekologi, biologi, dan keragaman sumber daya ekologi yang ada.

b) Social and Cultural Sustainability, yaitu memastikan bahwa pengembangan yang dilakukan memberi dampak positif bagi kehidupan masyarakat sekitar dan sesuai dengan kebudayaan serta nilai-nilai yang berlaku pada masyarakat tersebut.

c) Economic Sustainability, yaitu memastikan bahwa pengembangan yang dilakukan efisien secara ekonomi dan bahwa sumber daya yang digunakan dapat bertahan bagi kebutuhan di masa mendatang.

Pada hakikatnya prinsip pengembangan wisata secara berkelanjutan selalu memastikan bahwa pengembangan yang dilakukan berdasarkan perencanaan yang matang dengan tujuan yang jelas. Memastikan bahwa pengembangan yang dilakukan dapat memberikan manfaat dan memiliki nilai lebih yang dapat dirasakan oleh pengunjung wisata. Sehingga para pengunjung dan juga masyarakat sekitar memiliki kepuasan atas pengembangan yang dilakukan. Serta tidak memberikan dampak negatif bagi masyarakat maupun para pengunjung.

\section{2) Tujuan Pengembangan Wisata}

Pariwisata merupakan salah satu industri gaya baru yang mampu menyediakan pertumbuhan ekonomi yang cepat dalam hal kesempatan kerja, pendapatan, taraf hidup, dan mengaktifkan sektor produksi lain di dalam negara penerima wisatawan.

\section{PEMBAHASAN}

\section{Gambaran Umum Wisata Hutan Pinus}

\section{Sejarah Wisata Hutan Pinus}

Wisata Hutan Pinus adalah wisata hutan pinus yang berada di kabupaten Gorontalo. Tempat wisata hutan pinus ini berdiri atas tercetusnya oleh Swadaya masyarakat yang tergabung dalam Kelompok Pecinta Alam Green (KPA Green) Pekon Bina Pemberdayaan Desa Dulamayo. kelompok Lembaga Swadaya Masyarakat (LSM).

Available Online at http://journal.umgo.ac.id/index.php/Tulip

TULIP: Tulisan IImiah Pariwisata, Vol. 2, No. 2 Desember 2019, 149-163 


\section{TULISAN ILMIAH PARIMISATA}

Berdasarkan informasi dari DD selaku ketua Hutan Kemasyarakatan (HKM) bahwa:

"Hutan pinus yang ditanam sekitar berusia 50 tahun, hampir puluhan tahun hutan pinus ini dibiarkan secara alami. Bahkan banyak orang membuang sampah di hutan pinus ini. Biasanya tumpukan sampah plastik maupun lainnya mengganggu pemandangan. Ada yang sengaja membuang sampah disana dan juga sampah dari orang yang berhenti untuk beristrahat disana. Kemudian awal 8 tahun lalu ada keinginan untuk mengelola hutan ini, hingga tahun 2017 peluang untuk mengelola hutan lindung dari pemerintah dibuka lebar. Cikal bakal keinginan untuk mengelola hutan pinus ini menjadi tempat wisata, karena di Lampung itu belum memiliki wisata alam yang berbasis hutan pinus, dan baru ada ketika hutan ini dikelola dan dikembangkan, sehingga wisata ini memiliki potensi yang besar untuk dijadikan tempat wisata, serta keadaan masyarakat adalah mayoritas petani, yang mana merupakan petani musiman yang menghasilkan panen tidak setiap saat. Oleh sebab itu perlu dikembangkannya wisata-wisata yang berpotensi untuk membantu penghasilan masyarakat lebih dari sektor pertanian.

Berdasarkan cikal-bakal tersebut, pada akhirnya Wisata Pinus dibentuk dan dikelola dengan adanya kerjasama antar empat lembaga terkait yaitu, KPHL II Liwa (Kelompok Pecinta Hutan Lindung), KPA Green (Kelompok Pecinta Alam Hijau), HPPHL (Himpunan Pemuda Peduli Hutan dan Lingkungan) serta Kelompok HKM (Hutan Kemasyarakatan) yang membentuk konsorsium yang bernama West Land. Dengan delapan pengelola aktif yang secara terus menerus mengelola dan mengembangkan hutan pinus ini untuk dijadikan tempat wisata.

Luas hutan pinus yang dikelola menjadi tempat wisata adalah 1,7 hektar. Dengan Pengelolaan wisata hutan pinus Penasehat adalah Kepala Dinas Kehutanan Propinsi Gorontalo. Saat ini Wisata Pinus sangat terasa sejuk, bersih, indah dengan pinus yang tinggi, ramah dan nyaman untuk beristirahat atau berwisata di sana, juga sudah tertata rapi dan tersedia beberapa spot untuk Available Online at http://journal.umgo.ac.id/index.php/Tulip

TULIP: Tulisan IImiah Pariwisata, Vol. 2, No. 2 Desember 2019, 149-163 


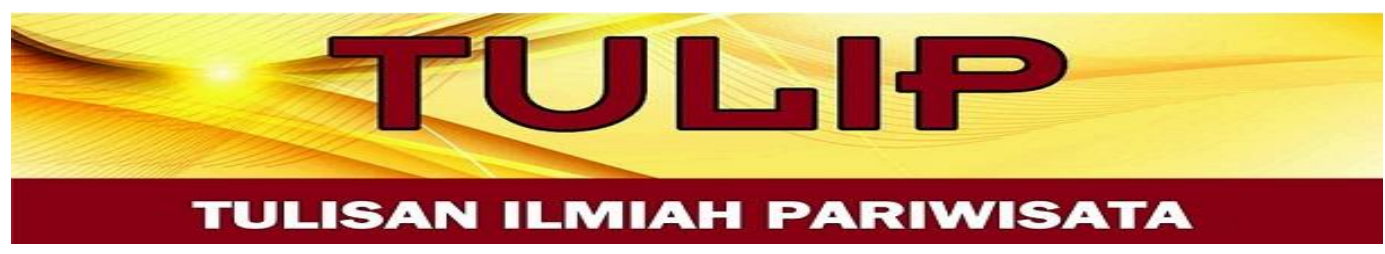

berfoto. Seperti hiasan bola-bola gantung warna-warni dan payung gantung warna-warni diikat diantara pepohonan, sehingga seperti melayang di udara. Gubuk yang terbuat dari bambu dan atap terbuat dari kakababan (ijuk aren), yang di buat menyerupai rumah (gubuk) kecil. Tempat-tempat duduk untuk bersantai, ada juga tempat bermain anak, ayunan santai, rumah pohon, flying fox, dan juga disediakan hammock yang bisa disewa untuk bersantai sembari duduk di hammock. yang diikat diantara pohon pinus, bisa juga untuk berfoto sambil duduk, atau berbaring di atas hammock.

\section{Lokasi Wisata Pinus}

Wisata Hutan Pinus berada di Desa Dulamayo, Kecamatan Limboto, Kabupaten Gorontalo, yang berada pada posisi $04^{\circ} 58^{\prime}$ BT sampai $104^{\circ} 30^{\prime}$ LS, dengan desa tertentu.

Penelitian ini dilakukan di Wisata Pinus Ecopark, Desa Sukapura, Kecamatan Sumber Jaya, Kabupaten Lampung Barat, yang mayoritas masyarakatnya beragama Islam sehingga tidak sedikit masyarakat yang telah mengetahui konsep etika bisnis islam dalam melakukan kegiatan ekonomi atau bermuamalah, khususnya dalam melakukan kegiatan promosi, baik promosi melalui media sosial maupun promosi yang dilakukan secara langsung.

Dalam penelitian ini peneliti mengadakan wawancara dengan Pengelola Wisata Pinus Ecopark, Dalam hal ini Pengelola Wisata Pinus Ecopark menggunakan beberapa Strategi promosi, sebagai berikut:

\section{a. Periklanan (advertising)}

Menurut bapak Asep selaku ketua area wisata Pinus Ecopark, periklanan adalah salah satu strategi yang digunakan untuk melakukan promosi wisata Pinus Ecopark dengan menggunakan media seperti media sosial diantaranya yaitu facebook, Instagram, Youtube, dan Google, dan juga menggunakan media cetak seperti buku-buku wisata yang diterbitkan oleh Dinas Kepemudaan Olahraga dan Pariwisata Kab. Gorontalo

Available Online at http://journal.umgo.ac.id/index.php/Tulip

TULIP: Tulisan IImiah Pariwisata, Vol. 2, No. 2 Desember 2019, 149-163 


\section{TULISAN ILMIAH PARIMISATA}

a. Penjualan Personal (personal selling)

Menurut bapak Nopianto selaku pengelola wisata Pinus Ecopark, Penjualan Personal adalah salah satu strategi yang digunakan untuk melakukan promosi wisata Pinus Ecopark dengan menawarkan langsung kepada masyarakat yang ada di sekitar dan juga pengunjung di dalam acara Even Rokok Djarum, Gudang Garam, Pelatihan dan Praktik Pembibitan Pinus, serta dalam acara Solidaritas Peduli Negeri yang di sponsori oleh Pinus Ecopark, dengan menginformasikan semua fasilitas yang ada di dalam wisata. ${ }^{100}$

Berikut ini gambar beberapa Even yang pernah dilakukan oleh Pengelola Wisata Pinus Ecopark:

\section{a. Promosi Penjualan (sales promotion)}

Menurut bapak Arif selaku pengelola wisata Pinus Ecopark, Promosi Penjualan adalah salah satu strategi yang digunakan untuk melakukan promosi wisata Pinus Ecopark dengan mengadakan tiket gratis selama 1 bulan diawal pembukaan wisata Pinus Ecopark. ${ }^{101}$

\section{b. Hubungan Masyarakat (Public relation)}

Menurut bapak dadang selaku ketua pengelola wisata Pinus Ecopark, Hubungan Masyarakat adalah salah satu strategi yang digunakan untuk melakukan promosi wisata Pinus Ecopark dengan melakukan kerjasama yang baik dengan Pemerintah Daerah, dan juga Dinas Kepemudaan Olahraga dan Pariwisata Kabupaten Lampung Barat, guna menjalin hubungan internal yang baik.

\section{a. Pemasaran Langsung (direct marketing)}

Menurut bapak Johari selaku pengelola wisata Pinus Ecopark, Hubungan Masyarakat adalah salah satu strategi yang digunakan untuk melakukan promosi wisata Pinus Ecopark dengan pemasaran langsung kepada calon pelanggan yang diincar yaitu pengunjung yang ingin melakukan prewedding, sehingga di wisata pinus Ecopark membuka objek yang bisa digunakan untuk Prewedding dengan Available Online at http://journal.umgo.ac.id/index.php/Tulip

TULIP: Tulisan IImiah Pariwisata, Vol. 2, No. 2 Desember 2019, 149-163 


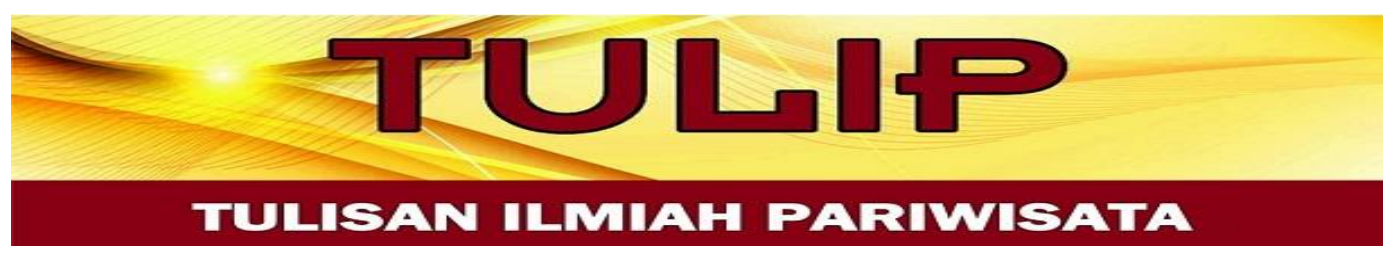

biaya yang terjangkau mulai dari Rp 150.000-, hingga Rp 200.000-,.

\section{KESIMPULAN}

Berdasarkan hasil penelitian dan pembahasan maka dapat disimpulkan penelitian ini bahwa Respon Masyarakat Lokal Terhadap Pengembangan Hutan Pinus Sebagai Daya Tarik Wisata Di Desa Dulamayo Kabupaten Gorontalo, sudah baik. Hal ini dilihat dari respon masyarakat sekitar terhadap pengembangan wisata hutan pinus sebagai lokasi wisata berjalan dengan baik.

\section{Daftar Pustaka}

Abdurrahman, Nana Herdiana. Manajemen Strategi Pemasaran. Bandung: CV Pustaka Setia, 2015.

Abidin, Zainal, dan Hutami P. Puspitasari. Mina Bisnis Ikan Cupang. Malang: UB Press, 2018.

Andi. Wawancara. Sukapura: 23 November, 2019.

Arif, Saidal. -Analisis Ekonomi Islam Tentang Pengembangan Objek Wisata Sebagai Sumber Pendapatan Asli Daerah.\| Skripsi, IAIN Raden Intan Lampung, 2015.

Asriandy, Ian. - Strategi pengembangan obyek wisata air terjun Bissappu di kabupaten bantaeng.ll Skripsi, Universitas Hasanuddin Makassar, 2016.

Astuti, Marhanani Tri, dan Any Ariani Noor. -Daya Tarik Morotai Sebagai Destinasi Wisata Sejarah Dan Bahari.\| Jurnal Kepariwisataan Indonesia Vol. 11 No. 1 Juni (2016).

Atiko, Gita, Ratih Hasanah Sudrajat, dan Kharisma Nasionalita. -Analisis Strategi Promosi Pariwisata Melalui Media Sosial Oleh Kementerian Pariwisata Ri (Studi Deskriptif Pada Akun Instagram @Indtravel).\| Jurnal Sosioteknologi Vol. 15, No 3, Desember (2016).

Bahiyah, Choridotul, Wahyu Hidayat R, dan Sudarti. -Strategi Pengembangan Potensi Pariwisata Di Pantai Duta Kabupaten Probolinggo.\| Jurnal Ilmu Ekonomi Vol 2 Jilid 1 (2018).

Batilmurik, Ridolof W., dan Hans A Lao. -Pengembangan Model Ekonomi Kreatif bagi Masyarakat di Daerah Objek Wisata Bahari Kabupaten Kupang Nusa Tenggara Timur.\| Jurnal Penelitian Manajemen Terapan (PENATARAN) Vol. 1 No. 1 (2016).

Available Online at http://journal.umgo.ac.id/index.php/Tulip

TULIP: Tulisan IImiah Pariwisata, Vol. 2, No. 2 Desember 2019, 149-163 
Betari Avinda, Chintiya, I Nyoman Sudiarta, dan Ni Made Oka Karini. —Strategi Promosi Banyuwangi Sebagai Destinasi Wisata (Studi Kasus Pada Dinas Kebudayaan Dan Pariwisata).\| Jurnal IPTA Vol. 4 No. 1 (2016).

Bungin, Burhan. Metodologi Penelitian Sosial dan Ekonomi. Jakarta: Kencana, 2013.

Cahya Nurhadi, Febrianti Dwi, Mardiyono, dan Stefanus Pani Rengu. - Strategi Pengembangan Pariwisata Oleh Pemerintah Daerah Terhadap Pendapatan Asli Daerah (Studi Pada Dinas Pemuda, Olahraga, Kebudayaan DanPariwisata Kabupaten Mojokero).॥ Jurnal Administrasi Publik (JAP) Vol. 2, No. 2 (t.t.).

D Manafe, Janri, Tuty Setyorini, dan Yermias A Alang. -Pemasaran Pariwisata Melalui Strategi Promosi Objek Wisata Alam, Seni Dan Budaya.\| Bisnis Vol. 4, No. 1, Juni (2016).

Djakfar, Muhammad. Etika Bisnis Menangkap Spirit Ajaran Langit dan Pesan Moral Ajaran Bumi. Jakarta: Penebar Plus, 2012.

Fahmi, Irham. Etika Bisnis Teori, Kasus, dan Solusi. Bandung: Alfabeta, 2015. Faidah, Na'imatul. - Strategi Promosi Wisata Religi di Kabupaten Wonosobo.ll

Skripsi, UIN Sunan Kalijaga, 2017.

Fathullah, Lisken Situmorang, Nurka Cahyaningsih, Ichwanto Nuch, dan Martua Sirait. - Perubahan Status Kawasan Hutan Guna Menjawab Permasalahan Kemiskinan dan Ketahanan Pangan: Studi Kasus dari Marga Bengkunat dan Pekon Sukapura, Kabupaten Lampung Barat.,\| t.t.

Fatihudin, Didin, dan Anang Firmansyah. Pemasaran Jasa: Strategi, Mengukur Kepuasan dan Loyalitas Pelanggan. Yogyakarta: Deepublish, 2019.

Fatoni, Abdurrahmat. Metodologi Penelitian \& Teknik Penyusunan Skripsi.

Jakarta: Rineka Cipta, 2011.

Fitriana, Evi. - Strategi Pengembangan Taman Wisata Kum Kum Sebagai Wisata Edukasi Di Kota Palangkaraya.\| Jurnal Pendidikan Geografi Nomor 2, Juni (2018).

Hadi, Firdausia. - Kajian Potensi Dan Strategi Pengembangan Wisata Pantai Syari'ah (Studi Di Pulau Santen Kabupaten Banyuwangi).\| Jurnal MD Vol. 3 No. 1/ Januari-Juni (2017).

Hadi, Sutrisno. Metodologi Penelitian Research 1. Yokyakarta: Yayasan Penerbitan Fakultas Psikologi UGM, 1981.

Handayani, Estu, dan Mohamad Dedi. -Pengaruh Promosi Wisata Bahari Dan Kualitas Pelayanan Terhadap Peningkatan Jumlah Kunjungan

Available Online at http://journal.umgo.ac.id/index.php/Tulip

TULIP: Tulisan IImiah Pariwisata, Vol. 2, No. 2 Desember 2019, 149-163 


\section{TULISAN ILMIAH PARIMISATA}

Wisatawan Di Pelabuhan Muncar Banyuwangi.॥ Jurnal Wira Ekonomi Mikroskil Volume 7, Nomor 02, Oktober (2017).

Haris, Abd. Etika HamkaKonstruksi Etik Berbasis RasionalReligius.Yogyakarta: LKIS Yogyakarta, 2010. 